\title{
Students' Elements of Motivation in Joining the EFL Virtual Classroom Using the Zoom Application During the Covid 19 Pandemic
}

\author{
Ahmad Heki Sujiatmoko \\ Universitas Negeri Malang \\ Jl. Semarang No. 05 Malang \\ ahmad.heki.fs@um.ac.id \\ Article History: Submitted on $9^{\text {th }}$ June 2021; Accepted on $7^{\text {th }}$ December 2021; \\ Published on $30^{\text {th }}$ December 2021
}

\begin{abstract}
The students' motivation in learning has been a crucial issue for many researchers so far. It is because motivation takes an important role to support the students' learning achievement. Hence, motivation cannot be separated from the teaching and learning activities conducted by the EFL teachers. This current research was aimed at investigating the elements of the students' motivation in joining the EFL virtual learning activities using the zoom application during the covid 19 pandemic. The research applied a qualitative descriptive approach. To collect the data, the researcher observed one elective class and interviewed some students from the class investigated. The results revealed that the students' motivation was mostly influenced by the positive effect related to the learning situations created by the teacher when using the zoom application to conduct the teaching and learning activities. This also implied that the zoom application could lead the teachers to think of being creative in conducting the virtual teaching and learning activities.
\end{abstract}

Keywords: Students' motivation, EFL virtual classroom, The zoom application, The covid 19 pandemic

\section{INTRODUCTION}

The students' learning achievements can be gained by various factors. One of the crucial factors that must be owned by the students for getting their learning achievements is motivation. In learning English, for instance, motivation can be the key to success for the students (Chen, Warden, and Chang 2005; Cle'ment, Dornyei, and Noels 1994; Crookes and Schmidt 1991). As a foreign language, students need to have a good motivation to learn English. In other words, motivation has some big contributions in EFL classrooms such as improving the students' confidence in doing some oral 
practices with native speakers (Hsu, 2018), and supporting the students to be creative in sharing ideas during the learning process (Al-Harby, 2012).

Motivation is known as one of the affective attributes that the students may perform during the teaching and learning activities done. In this case, the students are recognized to be highly motivated in doing something when they have a motive (Ushioda \& Dornyei, 2012). It means that the motivation owned by the students cannot appear by itself. There must be some factors that can support them to build their motivation for doing something such as joining and being active during the learning activities.

Gardner (2001) explains that three elements of motivation may develop in a person's life as the tool to move him or her to do or get something wanted. The first is effort. An effort can be depicted as the real acts performed by a person to support him or her in reaching the goals expected. The effort can be planned with an intention and be realized through some performances as the real actions. In short, motivation will be nothing without efforts performed by a person. Motivation cannot only be orally stated through the mouth, but it needs proving through some real actions performed as the depiction of the efforts done. In learning English as a foreign language, for instance, a student who is assumed to have good motivation must be able to act or perform something as the effort $\mathrm{s} /$ he has. In this case, in trying to have the speaking skill, s/he must do or practice some activities related to get the improvements of his or her speaking skill such as pronouncing, giving opinions, having discussions, and so on.

The second is desire. The desire is concerned with a person's need, want, ambition, and expectation to reach the goal targetted. Every human cannot be separated from their imagination for reaching something. This may result from want, ambition, and expectation which may appear because of interests. In learning English as a foreign language, a person may have a great desire due to some ambitions in the future. For example, a person wants to learn English because s/he has a plan to study or work in America after graduating the school. In this case, s/he has a desire concerning the way how $\mathrm{s} /$ he can make his or her dream of studying or working abroad come true in the future.

The third is positive affect. This element is related to the situations which can support a person to do or get something expected. Motivation cannot be separated from the existing situations in the environment or place where s/he lives, studies, or works. Even, sometimes when the situation does not give or contribute for him or her to get something expected, s/he will not keep her or his motivation. In learning English as a foreign language, for instance, the teachers are claimed to be able to create supportive learning situations for the students. It is crucial to help the students get highly motivated to learn. This can be done through using technology in making the teaching and learning activities more interesting or attractive. 
Today teaching and learning activities cannot be separated from the use of technology. It is a fact that most of the EFL teachers feel that using technology such as videos, projectors, and pictures can make the teaching and learning activities conducted to be more interesting (Yunus et.al, 2013). In this case, the technology can facilitate the teachers to hold the teaching and learning activities better since it can connect the students with the learning content to everyday life (Cam \& Tran, 2017; Hwang et al., 2016). Besides, most of the teachers and students have been familiar with the use of technology for supporting the teaching and learning activities conducted (Megawati et al., 2020).

There are many kinds of technological tools that have developed and been used by people in the world. One of the technological digital tools that can be used to support learning activities is the zoom application. The zoom application is a digital application having the facility to connect the teacher and students within different locations and distances. In this case, the teachers may hold the meeting with the students directly in a long distance at the same time. Hence, the zoom application is suitable for having or building a synchronous learning system in online or virtual learning activities. Specifically, using the zoom application can help the students negotiate the meaning and enhance their communicative competence (Vurdien, 2019), develop intercultural competence (Giralt \& Jeanneau, 2016), contribute to improving the students' speaking skills (Lim \& Pyun, 2016), and track the students' learning process (Chang, 2007). Ultimately, the present study will investigate the efficiency of the zoom technology as an educational tool to motivate the students in joining the online or virtual EFL classroom due to the covid 19 pandemic.

Regarding this, many EFL teachers are claimed to think about the students' motivation in learning. It is because since the covid 19 pandemic appeared, most of the teaching and learning activities are conducted through the online system or virtually. In this case, both the teacher and students require to use some digital applications as a tool for helping them conduct the virtual learning activities successfully. One of the digital applications that can be used for supporting the implementation of the online or virtual EFL classroom is the zoom application.

However, whatever the online or virtual learning activities conducted by using the zoom application may not be similar to what happens in the offline learning activities. In this case, both the teacher and students may feel something different in terms of the learning situations created. This condition may affect or influence the students' motivation in joining the online or virtual learning activities. Tasneem (2021) found that online learning activities could reduce the students' learning motivation. That's why the current research was crucially conducted to know some elements that may affect the students' motivation in joining the online or virtual EFL classrooms. 
Based on the rational explanation above as the main problem faced by the teachers in conducting the virtual EFL learning activities during the covid 19 pandemic, the researcher wanted to reveal what elements of motivation the students had when joining the EFL online or virtual classrooms using the zoom application and in what way the students performed each element of motivation in joining the EFL online or virtual classroom using the zoom application.

\section{METHOD}

The study was concerned with describing and analyzing the elements of motivation that the students owned and built when joining the EFL virtual classroom using the zoom application during the covid 19 pandemic. The investigation of the study was done through natural, deep, and holistic realities to be interpreted to get rich information about the phenomenon happening. That's why, the study used a qualitative descriptive approach within a case study design (Cohen et al., 2005; Creswell, 2012).

The study was done at one modern school in Gresik which had been familiar with the use of technology to support the teaching and learning activities held. All teachers at this school were also often given some pieces of training about using or applying the technology in the process of teaching and learning activities. Meanwhile, most of the students who studied were from rich families who lived downtown. Their parents varied in their jobs such as businessmen, doctors, lecturers, civil servants, and so on. Hence, most of the students were ready to join the virtual learning activities with the use of technology.

Specifically, there was only one elective class to be investigated. The class investigated was chosen since it was taught by a novice teacher who had been teaching for several months. Hence, it became something interesting to know the students' motivation in joining the virtual class handled by her. It was assumed that even though the teacher investigated did not have any experience, she could have some new strategies with the use of technology such as digital applications like the zoom. She got more experienced and familiar with the digital applications than some teachers who had been old and could not use or apply the digital applications for supporting the teaching and learning activities held. In addition, there were some selected students based on their learning achievement levels or predicates.

To get the data, the researcher held an observation several times to the class investigated. In doing the observation, the researcher conducted the non-participant observation. In this case, the researcher just joined the zoom meeting held by the teacher when holding the teaching and learning activities. So, the researcher did not include or interfere with the process of the teaching and learning activities happening.

Besides, the researcher also gave the questionnaires to the students from the class investigated. There were 25 students in the class investigated, 
but there were only 10 students who were willing to answer the questionnaires. The questionnaires were shared through a google form. In this case, the researcher just needed to share the link with the students. To make sure that the students were willing to give their opinions through the questionnaires shared, the researcher also asked for help from the teacher so that the teacher could give the instructions to the students selected to fill in or give their responses to the questionnaires given.

In analyzing the data, the researcher applied a procedure containing the three current flows of activity namely data condensation, data display, and conclusion drawing or verification (Miles et al., 2014). In this case, in condensing the data, the researcher needed to select, focus, simplify, abstract, and transform the documents and empirical materials taken from the observations and questionnaires. Then, in displaying the data, the researcher used diagrams to perform and organize the data analyzed. After that, in concluding, the researcher represented, reported, and interpreted the data.

\section{FINDINGS AND DISCUSSION}

\section{Students' Motivation Elements}

During the spread of the covid 19 pandemic, many teachers have got worried about the students' motivation in learning. It is because the teaching and learning activities are done in a new way that has never been applied before. It is known as the online or virtual learning system. In doing this, the EFL teachers are claimed to be able to have some strategies in teaching through the use of technology like digital applications. One of the digital applications that are commonly used as the alternative way to fulfill the teachers' needs to hold the synchronous meeting with the students directly without worrying about the locations and distances at the same time is the zoom. The zoom application is known as the application with various facilities such as holding the video conference in which the teacher and students can meet directly.

Based on the observation and questionnaires shared with the students, it was found that among the three elements of motivation performed by the students during their participation in joining the EFL virtual classrooms, the positive effect element was the highest motivation element that the students had. It was about $50 \%$. This element was concerned with their enjoyment in joining the virtual learning activities conducted by the teacher. In this case, they were found to enjoy the virtual learning activities due to the existence of the variety of the learning activities created by the teacher with the use of the zoom application. In other words, the teacher was successful to create interesting or attractive learning situations through some learning activities which could improve and increase the students' motivation.

Meanwhile, other elements of motivation were also performed by the students with different and lower percentages. Particularly, The second element of motivation was concerned with the efforts. It was about $35 \%$. 
This element performed the students' expectation to reach good learning achievements. In this case, they were still motivated to join the class virtually since they wanted to understand the materials given by the teacher for getting high scores and improving their learning achievements.

The other element of motivation was desire. This element of motivation appeared as the last element of motivation performed by the students. it was about $15 \%$. This element was concerned with the students' ambition related to their future life. It meant that the students tried to connect what they did through learning English with their ambitions in the future such as continuing their studies to university and getting jobs that needed English competence. The data can be seen in figure 1 below.

Figure 1:

Students' Elements of Motivation in Joining the EFL Virtual Classrooms Using The zoom Applications During The covid 19 Pandemic

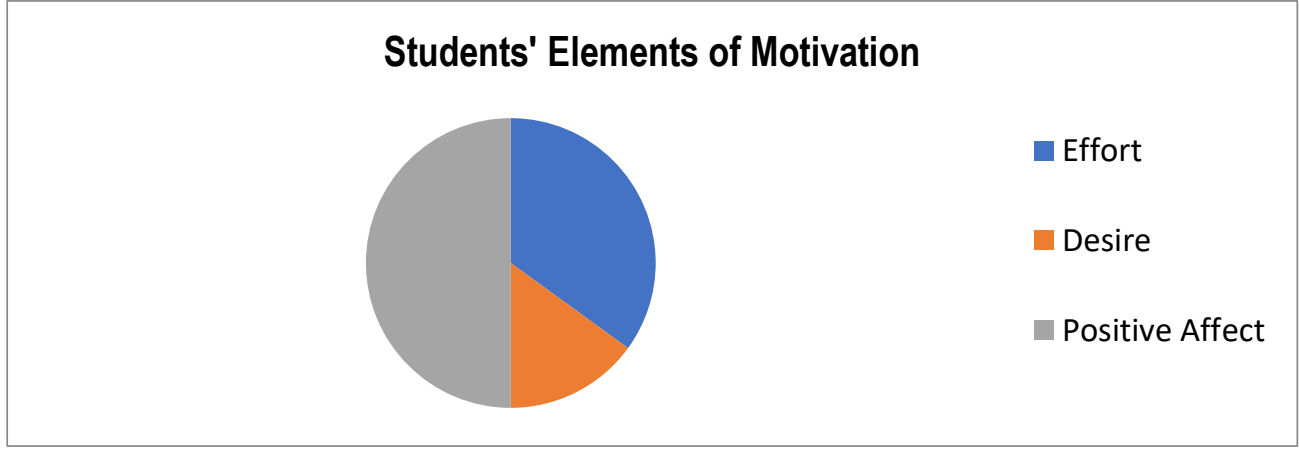

The findings of the study revealed that the positive effect had given the biggest influence on the students' motivation. What made this element could attract the students was the learning situations created by the teacher. This was also similar to the findings revealed by Kormos \& Csizer (2014). In this case, the implementation of the EFL virtual learning activities promoted some challenges faced by the teacher in terms of her strategies to provide the students with some interesting learning activities through the zoom application. In this case, when the teacher was successful to provide some interesting learning activities, it could change the learning situations to be more attractive for the students. Hence, the students became unconsciously interested in joining the virtual classrooms held (Al-Hoorie, 2016). It could also be an indication that the teacher's creativity was good. Avila (2015) in her study also found that the teachers' creativities became the barometer for measuring the success of holding the learning activities. In other words, the implementation of the online or virtual learning activities needed to sustain with teacher's good capacity in utilizing the technology such as the zoom application in producing various kinds of learning activities that could motivate the students better (Lin \& Lan, 2015). 


\section{Factors Building Students' Motivation Elements}

Each element of the motivation performed by the students could not be separated from the factors influencing them. In this case, each element of the motivation had different factors that made the students perform their tendency in building the motivation of learning virtually. The results of the study showed that the highest element of motivation known as the positive affect had some factors. They were attractive learning activities, feeling better than offline, and staying at home. Among those three factors, various learning activities became the most important factor as the depiction of the positive effect element of motivation. It was $50 \%$. Meanwhile, feeling better than offline as another element got $30 \%$, and staying at home as the other elements also got $20 \%$. This can be seen from the following figure 4.2 .

Figure 2:

Positive Affect Factors of Motivation in Joining the EFL Virtual Classrooms Using The zoom Applications During The covid 19 Pandemic

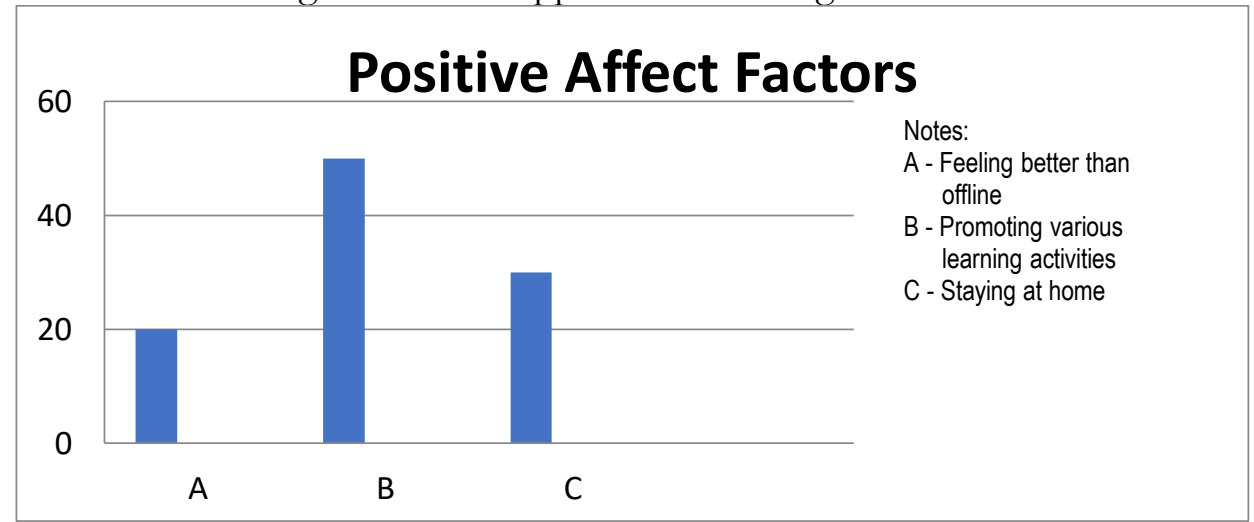

The figure 2. above indicated that the zoom application provided some facilities which could make the teacher creative in giving various learning activities. The variety of the learning activities held by the teacher was successful to motivate the students in joining the online or virtual learning activities done. This was also in accordance with Kim (2020). It was found that the teacher who was creative and innovative in providing various learning activities when using the zoom application could motivate the students in joining the online or virtual classrooms.

In addition, the use of the zoom application also entailed some performances done by the students. It meant that the teacher also had a big chance to use the performance-based assessments through using the zoom application in holding the learning activities. The result showed that the students were very enthusiastic to produce any performance for proving their competencies. Prastikawati (2018) found that the students had good responses to the learning activities done when the teacher used some performance-based assessments. 
Another element of motivation also had some factors influencing the students' motivation in joining the EFL online or virtual classrooms using the zoom application. The result of the research found that there were some factors derived from the element of motivation known as effort. They were obeying school regulations, getting to know the foreigners, feeling important to the learning activities, and getting easy-to-understand the materials. Among those factors, getting easy-to-understand the materials was the highest factor that could influence the students' motivation in joining the EFL online or virtual classrooms using the zoom application. It was $40 \%$. Meanwhile, the other factors mentioned above only got 30\%, 20\%, and 10\%. This can be seen in figure 3 below.

Figure 3:

Effort Factors of Motivation in Joining the EFL Virtual Classrooms Using The zoom Applications During The covid 19 Pandemic

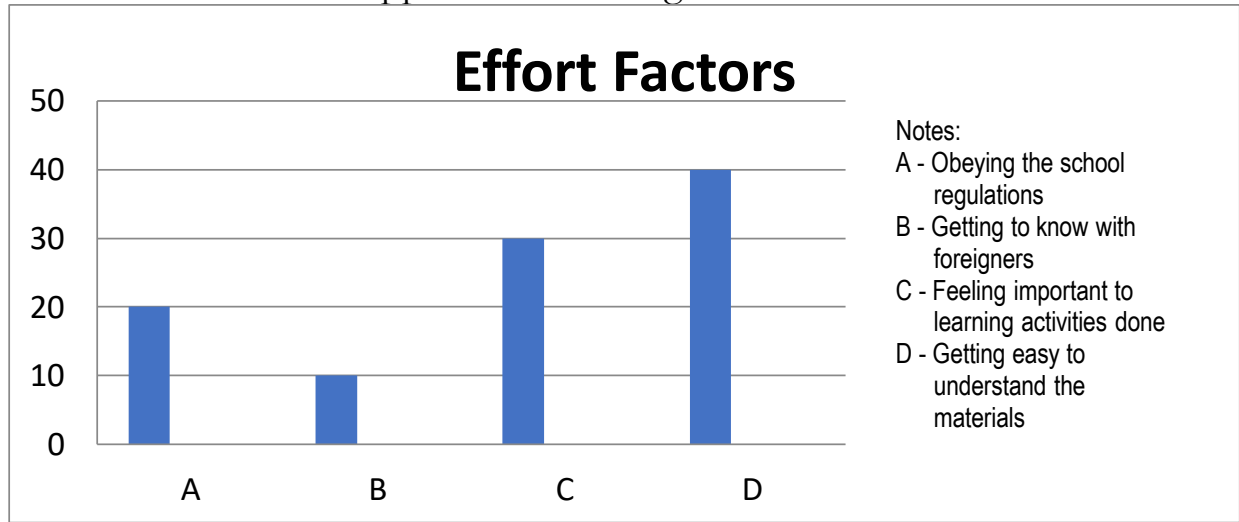

Figure 3 above indicated that using the zoom application in the online or virtual classrooms could invite the students to perform some efforts for showing their motivation in learning English. One of the efforts was that the students tried hard to learn English better through using zoom. It meant that using the zoom application could make them learn English easier. They could get the explanations given by the teacher more clear since they could see the materials explained through the act of sharing screen done by the teacher. Some discussion could also be done with the peer. Hence, some questions and answers related to the materials learned could be caught by the students well. Nuryanto (2021) also revealed that the use of zoom could enhance the students' skills and motivation in learning English.

The last element of motivation known as desire also entailed some factors influencing the students' motivation. This element was concerned with the students' future ambition containing some factors such as getting a good job, leading to being professional worker, and supporting the next study at university or college. Among those factors of this element, supporting the next study at university or college got the highest score, it was 50\%. The other factors just got $30 \%$ and $20 \%$ for each. This can be seen from figure 4 below. 
Figure 4:

Desire Factors of Motivation in Joining the EFL Virtual Classrooms Using The zoom Applications During The covid 19 Pandemic

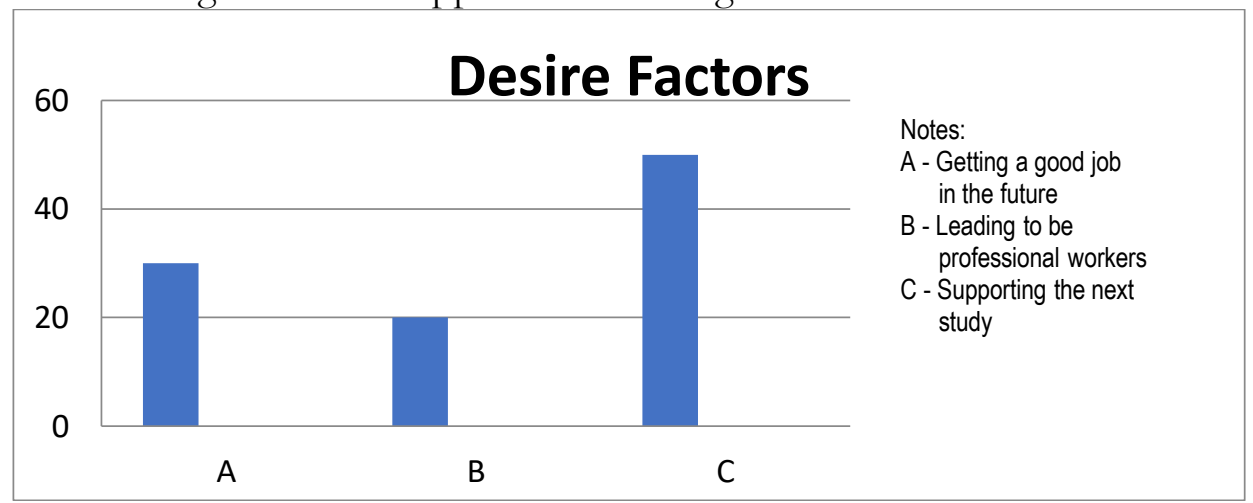

Figure 4 above indicated that using the zoom application in learning English virtually was not only concerned with the present expectation for getting better learning achievements but also was related to what the students expected about their future. In this case, the students were found to think about their ambitions in the future. Specifically, there were three things they could think of joining the EFL online or virtual classrooms - getting a good job, being professional worker, and supporting the next study at university or college.

What was thought by the students was that using the zoom application also gave some potentials concerning their future. Through using the zoom, they could be familiar in preparing themselves for working, being good workers, or even supporting their study. However, the students were found to tend to relate it with their plans to continue their studies at university or college. They believed that at university or college, the use of technology of digital applications like zoom could be something important. It could not be avoided or even it became the best alternative for conducting online or virtual learning activities due to face the revolution of the industrial era 5.0.

In short, the elements of motivation consisting of positive affect, effort, and desire within each existing factor needs to be thought and considered by the EFL teacher in trying to lead the students to keep and improve their motivation in joining the online or virtual learning activities using the zoom applications. Besides, the EFL teachers are claimed to recognize the facilities provided by the zoom application so that they can build creativity and innovation to produce various teaching strategies resulting in some interesting learning situations which can motivate the students better.

The students' motivation may not stagnate. But it will change or shift in accordance with the learning situations built and developed by the teachers (Gardner, 2010). In the pandemic situations in which it is recommended that most of the EFL teaching and learning activities be held through the online system with the use of technology of the digital applications, the EFL 
teachers are challenged to be creative and innovative in providing or holding the learning activities which can make the students get highly motivated in learning.

\section{CONCLUSION}

The contribution and importance of the learning motivation for the students will never decrease or lose. Even, it will be the biggest attention that must be given or thought to by the EFL teachers. Conducting online or virtual learning activities is not similar to what happens in offline learning activities especially in terms of the elements of motivation performed by the students including positive affect, effort, and desire. Hence, every teacher is claimed to be able to have some strategies in order that the students can keep and increase their motivation when joining the online or virtual learning activities held. One of the strategies that can be done is by using the zoom application. The zoom application can be the alternative tool for holding the synchronous learning system in which the teacher can meet the students directly within different locations and distances at the same time.

By using the zoom application, the teachers have some potentials to create and develop various kinds of learning activities that can motivate the students to learn better such as presentation, simulation, conversation, and so on. What makes using the zoom can be the alternative way to support the teaching and learning activities held is that it can create motivating learning situations with various learning activities. Hence, the online or virtual learning activities will not be an obstacle for both the teachers to keep and promote the improvements of the students' learning achievements.

\section{ACKNOWLEDGEMENT}

This research is fully supported by PNBP of Faculty of Letters, Universitas Negeri Malang for funding in 2021.

\section{REFERENCES}

Al-Harbi, G. (2012). Primary school teachers' perceptions regarding ICT usage and equipment in Kuwait. Journal of International Education Research, 8(1), 55-62. https://doi.org/10.19030/jier.v8i1.6696.

Al-Hoorie, A. H. (2016). Unconscious motivation. Part II: Implicit attitudes and L2 achievement. Studies in Second Language Learning and Teaching, 6, 619-649.

Avila, H. A. (2015). Creativity in the English class: Activities to promote EFL learning. HOW, 22(2), 91-103. https://doi.org/10.19183/how.22.2.141. 
Cam, L., \& Tran, T. T. M. (2017). An evaluation of using games in teaching English grammar for first year English-majored students at Dong Nai Technology University. International Journal of Learning, Teaching and Educational Research, 16(7), 55-71.

Cohen, L. Manion, L. and Morrison K., (2005). Research Methods In Education. London: Taylor \& Francis e-Library.

Chen, J., C. Warden, and H.T. Chang. (2005). Motivators that do not motivate: The case of Chinese EFL learners and the influence of culture on motivation. TESOL Quarterly, 3(9), pp. 609 - 633.

Cle 'ment, R., Z. Do "rnyei, and K.A. Noels. (1994). Motivation, selfconfidence and group cohesion in the foreign language classroom. Language Learning, 4(4), pp. 417 - 448.

Creswell, John W. (2012). Educational Research: Planning, Conducting, and Evaluating Quantitative and Qualitative Research (4 ${ }^{\text {th }}$ Edition). New Jersey: Pearson education Inc.

Crookes, G., and R. Schmidt. 1991. Motivation: Reopening the research agenda. Language Learning, 4(1), pp. 469 - 512.

Gardner, R. C. (2010). Motivation and second language acquisition: The socioeducational model (Vol. 10). New York: Peter Lang.

Gardner, R.C. (2001). Integrative motivation and second language acquisition. In Dornyei, Z. and Schmidt, R (eds.), Motivation and second language acquisition (pp. 1-19). Honolulu, HI: national Foreign Language Resource Center.

Giralt, M. \& Jeanneau, C. (2016). Preparing Higher Education Language Students for Their Period Abroad Through Tele-collaboration. The ITELL Project," AISHE-J, 8(2), 201 - 234.

Hsu, Ting Chia. (2018). Using a concept mapping strategy to improve the motivation of EFL students in Google Hangouts Peer-Tutoring Sessions with native speakers. Interactive Learning Environments, 23(3), p. 01 - 14. DOI: 10.1080/10494820.2018.1463268.

Hwang, G. J., \& Wang, S. Y. (2016). Single loop or double loop learning: English vocabulary learning performance and behavior of students in situated computer games with different guiding strategies. Computers \& Education, 102 , 188-201. https://doi.org/10.1016/i.compedu.2016.07.005.

Kim, HyeJeong. (2020). The efficacy of the zoom technology as an educational tool for English reading comprehension achievement in EFL classroom. International Journal of Advanced Culture Technology, 8(3), pp. 198-205.

Kormos, J., \& Csizer, K. (2014). The interaction of motivation, selfregulatory strategies, and autonomous learning behavior. Journal of Language Teaching and Research. TESOL Quarterly, 48(2), 275-299. 
Lim, B. \& Pyun, D. (2016). Korean foreign language learning: Video conferencing with native speakers. In C. Wang and L. Winstead (Eds.), Handbook of research on foreign language education in the digital age, pp. 253276, Hershey, PA: Information Science Reference, July 2016. DOI: 10.4018/978-1-5225-0177-0.ch012.

Lin, T. J., \& Lan, Y. J. (2015). Language learning in virtual reality environments: Past, present, and future. Educational Technology \& Society, 18(4), 486-497.

Megawati, F., Hasanah, F.N., Aulina, C.N., Avivi, M., \& Muntiari, N.S. (2020). How confident are EFL prospective teachers toward technology? Lensa: Kajian Kebahasaan, Kesusastraan, dan Budaya, 10(2), pp. 137-151. DOI: https://doi.org/10.26714/lensa.10.2.2020.137-151.

Miles, Mattew B \& A. Michael Huberman. (2014). Qualitative Data Analysis: An Expanded Sourcebook. California: Sage Publication, Inc.

Nuryanto, M. (2021). Fostering success and motivating EFL learners using the zoom meeting: A synchronous learning strategy. Anglophile Journal, 1(2), pp. 01 - 12.

Prastikawati, E.F. (2018). EFL learners' responses on the use of performancebased assessments. Lensa: Kajian Kebahasaan, Kesusastraan, dan Budaya, 8(1), pp. 75-86. DOI: https://doi.org/10.26714/lensa.8.1.2018.75-86.

Tasneem, N. (2021). Learner motivation and engagement in virtual EFL classes at tertiary level during the pandemic. Lensa: Kajian Kebahasaan, Kesusastraan, dan Budaya, 11(1), pp. 107-123.

DOI: https://doi.org/10.26714/lensa.11.1.2021.107-123

Ushioda, E. (2008). Motivation and good language learners. In C, Griffiths (Ed.), Lessons from good language learners. (pp. 19-34). Cambridge: Cambridge University Press

Ushioda, E. \& Z. Dornyei. 2012. Motivation. In The Routledge handbook of second language acquisition, ed. S. Gass and A. Mackey, 396409. New York: Routledge.

Vurdien, R. (2019). Video conferencing: Developing students' communicative competence. Journal of Foreign Language Education and Technology, 4(2), pp. 269-298.

Yunus, M. M., Salehi, H., \& John, D. S. A. (2013). Using visual aids as a motivational tool in enhancing students' interest in reading literary texts. Proceedings of the 4th International Conference on Education and Educational Technologies (EET 13), 114-117. Retrieved from https://arxiv.org/abs/1305.6360. 